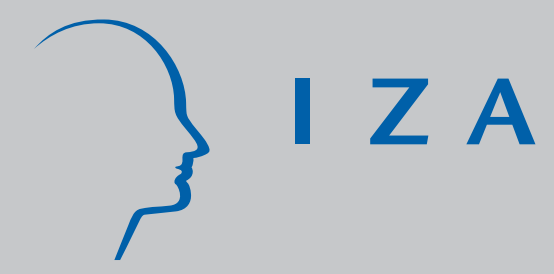

IZA DP No. 3864

The Regional Dimension of Collective Wage Bargaining:

The Case of Belgium

Robert Plasman

Michael Rusinek

Ilan Tojerow

November 2008 


\title{
The Regional Dimension of Collective Wage Bargaining: The Case of Belgium
}

\author{
Robert Plasman \\ Free University of Brussels, DULBEA \\ Michael Rusinek \\ Free University of Brussels, DULBEA \\ Ilan Tojerow \\ Free University of Brussels, DULBEA \\ and IZA
}

Discussion Paper No. 3864

November 2008

\author{
IZA \\ P.O. Box 7240 \\ 53072 Bonn \\ Germany \\ Phone: +49-228-3894-0 \\ Fax: +49-228-3894-180 \\ E-mail: iza@iza.org
}

\begin{abstract}
Any opinions expressed here are those of the author(s) and not those of IZA. Research published in this series may include views on policy, but the institute itself takes no institutional policy positions.

The Institute for the Study of Labor (IZA) in Bonn is a local and virtual international research center and a place of communication between science, politics and business. IZA is an independent nonprofit organization supported by Deutsche Post World Net. The center is associated with the University of Bonn and offers a stimulating research environment through its international network, workshops and conferences, data service, project support, research visits and doctoral program. IZA engages in (i) original and internationally competitive research in all fields of labor economics, (ii) development of policy concepts, and (iii) dissemination of research results and concepts to the interested public.
\end{abstract}

IZA Discussion Papers often represent preliminary work and are circulated to encourage discussion. Citation of such a paper should account for its provisional character. A revised version may be available directly from the author. 


\section{ABSTRACT \\ The Regional Dimension of Collective Wage Bargaining: The Case of Belgium}

The potential failure of national industry agreements to take into account productivity levels of least productive regions has been considered as one of the causes of regional unemployment in European countries. Two solutions are generally proposed: the first, encouraged by the European commission and the OECD, consists in decentralising wage bargaining to the firm. The second solution, the regionalisation of wage bargaining, is frequently mentioned in Belgium or in Italy where regional unemployment differentials are high. The objective of this paper is to verify if the Belgian wage setting system, where industry bargaining has a national scope, indeed prevents regional productivity levels to be taken into account in wage formation. Using a very rich linked employer-employee dataset which provides detailed information on wages, productivity, and worker's and firm's characteristics, we find that regional wage differentials and regional productivity differentials within joint committees ${ }^{2}$ are positively correlated. Moreover, this relation is stronger (i) for joint committees where firm-level bargaining is relatively frequent and (ii) for joint committees already sub-divided along a local line. We conclude that the current Belgian wage setting system (which combines interprofessional, industry and firm level bargaining) already includes mechanisms that allow regional productivity to be taken into account.

JEL Classification: $\quad$ D31, J31, J41

Keywords: $\quad$ wages, collective bargaining, federalism, regions, Belgium

Corresponding author:

Ilan Tojerow

Université Libre de Bruxelles (ULB)

Department of Applied Economics (DULBEA)

CP 140

Avenue F.D. Roosevelt 50

B-1050 Brussels

Belgium

E-mail: itojerow@ulb.ac.be

\footnotetext{
${ }^{2}$ Joint Committees are permanent bodies at the industry level in which employers' associations and trade unions are represented. Their main task is to oversee the conclusion of industry collective agreements by the organizations represented.
} 


\section{Introduction}

Within the framework of the debate over the relationship between the structure of wage bargaining and economic performances in Europe, the question concerning the regional dimension returns in a recurring way. The discussion often relates, in particular, to the capacity of wage-setting systems to take into account the important economic disparities between regions. Pench et al. (1999) support for example that a uniform fixation of wages across regions would not be adapted to local job markets. According to Davies and Hallet (2001), the important regional differences in unemployment observed in numerous European countries are due to the incapacity of the wage-setting systems to take into account the levels of productivity of the least productive regions. ${ }^{3}$ The predominance of national industry bargaining, in a large number of European countries, could explain this phenomenon. Accordingly, two types of answers are generally proposed in order to take into account the local environment in the establishment of wages. The first, supported by the European Commission (Davies and Hallet, 2001) and the OECD (OECD, 2006), consists of decentralising wage bargaining towards the company level. The second, which appears regularly in Belgium and in Italy ${ }^{4}$, two countries characterised by important regional differences in unemployment, consists of regionalising wage bargaining.

Within European countries, only Spain and Germany present a regionalised formation of wages. In Spain, Simón et al. (2006) note important variations in wages between regions as well as in wages agreed at the industry level as in actual paid wages. They deduce from this that the regional character of industry bargaining allows for a differentiation of wages between regions. However, these wage differences do not seem to fully reflect local conditions because of the phenomenon of inter-regional imitation within one same industry (Bande et al., 2008). In the case of Germany the regional differences in industry

\footnotetext{
${ }^{3}$ Other factors such as the differences in economic development, labour qualification and the lack of geographic mobility can also causes differences in unemployment between regions. (Davies et Hallet, 2001)

${ }^{4}$ For Italy, see EIRO (1998).
} 
agreed wages are rather weak although wage bargaining is held at the Landers level. The strongly coordinated character of wage bargaining between trade-union confederations and employer associations could explain this situation (Schnabel, 1999). In the countries where industry bargaining is not regionalised, the regional differences in wages vary significantly. In Italy, the important regional differences in unemployment do not seem to generate large wage disparities. For Dell'aringa and Pagani (2005), this can be explained by the existence of wages floor generated by industry agreements which would prevent wages from adapting themselves in the regions of low levels of productivity. The Italian example cannot, however, be carried over to all the countries without regionalised industry bargaining. Indeed, the level of regional wage differentials depends also in the degree of centralisation/coordination of wage bargaining. Vamvakidis (2008) analyses the relation between the degree of coordination of wage bargaining and the regional wage differentials $^{5}$ in 10 European countries between 1980 and 2000. His results indicate a negative relation between the degree of coordination of wage bargaining and the level of regional wage differentials. ${ }^{6}$ To sum up, the organisation of the formation of wages at the regional level appears not to be a sufficient condition, neither a necessary condition, for generating high levels of regional wage differences. It seems in fact, in this debate, that the regional character of the wage-setting systems brings less than the degree of centralisation/coordination of wage bargaining.

In Belgium, the regionalisation of wage bargaining is at the heart of current negotiations relative to a de-federalisation of employment policy. The partisans for the regionalisation of wage bargaining ${ }^{7}$ argue that the differences in productivity between regions cannot be reflected in a formation of wages at the federal level. They add that a negotiation at the Walloon level would be more sensitive to unemployment and would thus involve lower wages for this region.

\footnotetext{
${ }^{5}$ Expressed by the OECD index taking into account the level of bargaining and the formal or informal coordination between trade unions and employers.

${ }^{6}$ Quiet logically, these results are only relevant for the countries characterized by strong differences in regional levels of productivity.

7 Notably the Flemish christian democratic party (CDNV-NVA) and the Flemish liberal party (VLD).
} 
The present paper discusses the pertinence of a regionalisation of wage bargaining in Belgium in verifying, in an empirical manner, whether the actual wage-setting system (inter-professional agreement, followed by industry agreements, and eventually followed by firm-level agreements) is flexible enough to take into account the regional differences in productivity in the formation of wages.

A way of evaluating the pertinence of the regionalisation of wages in Belgium is to analyse its potential consequences. Bogaert (2008) supports for example that a regionalisation of wages would remove the moderating influence of "francophone" unemployment on Flemish wages. As an effect this would increase wages in Flanders and, through demonstration, would generate similar wage increases in Wallonia. The final result would be a higher increase of wages than in the current federal system. This phenomenon seems to be occurring in Spain where bargaining are already regionalized (Bande et al., 2008). Deschamps (2003) suggests that a regionalisation of wage bargaining would also increase the complexity of the system and would lead to administrative costs for firms that have production sites in more than one region. Deschamps (2003) also argues that a regionalisation of wages would pave the way to the regionalisation of social security. It would be indeed incoherent to restrict regionalisation solely on wages, and not on total labour costs. Therefore, the contributions to social security, which represents a large part of the total labour costs, would also be regionalised. This could, finally, affect the level of social security spending in the different regions.

Another way of assessing the relevance of the regionalisation of wages would be to discuss the argument that the current system of wage formation is incapable of taking into account the different regional levels of productivity. This approach has the advantage of being tested empirically. Several recent studies have tried to answer this question (Dejemeppe and Van der Linden, 2006; Plasman et al., 2007; Joskin et al., 2008). Their results seem to indicate that the average labour productivity is lower in Wallonia (Dejemeppe and Van der Linden, 2006; Joskin et al., 2008) but, in the same time, there already exists wage differences between regions (Dejemeppe and Van der Linden, 2006; Plasman et al., 2007). 
These wage differences, nonetheless, only take partially into account the differences in productivity. Indeed, according to Dejemeppe and Van der Linden (2006) and Joskin et al. (2008), the unit labour cost is, in average ${ }^{8}$ higher in Wallonia than in the rest of the country. The data used in this last analysis suffer nonetheless from two limitations: Firstly, they are macro-level data so they do not allow taking into account eventual composition effects. Secondly, they do not distinguish between salaried workers and selfemployed workers whose revenues are not determined by collective bargaining.

Based on these empirical results, one can legitimately ask how the current system could take into account the regional differences in productivity. The possibility to complete the national industry agreements by agreements at the firm level could be the explanation (Dejemeppe and Van der Linder, 2006; Plasman et al., 2007). Verly (2003) estimates that, in Belgium, approximately half of the employees is affected by a wage bargaining process on a level other than the national. On one hand, several joint committees are subdivided into sub-joint committees at the regional level. These joint committees cover nearly $16 \%$ of employees in the private sector. ${ }^{9}$ On the other hand, industry agreements can be completed by agreements at the company level. These concern nearly $27 \%$ of employees in the private sector. ${ }^{10}$ The existence of wage differences between regions could therefore be explained by these two mechanisms. In the current literature, only the study by Plasman et al. (2007) empirically establishes a link between the presence of regional wage differentials and company bargaining. However, no study investigates the influence of regional sub-joint committees.

The objective of this contribution is therefore double. First, we want to see if the current system of wage formation takes into account regional differences in productivity. To do so, we estimate regional wage differentials in each joint committee and we check if these differentials are correlated to regional productivity differentials in these joint committees. Second, we want to identify the mechanisms that allow for the regional differences in

\footnotetext{
8 There are differences across sectors.

${ }^{9}$ Structure of Earnings Survey, 2003.

${ }^{10}$ Ibidem.
} 
productivity to be reflected in wages. For this, we check if the correlation between the regional differences in wages and in productivity varies according to the structure of collective bargaining. More precisely, we compare decentralised joint committees (i.e. joint committees where the percentage of employees covered by a firm agreement is relatively high) to centralised joint committees, as well as joint committees subdivided in regional sub-joint committees to those that are not.

The rest of the article is divided into five sections. In the first section, we present the dataset used for the estimations. In the second section we check if there exist differences in wages between regions. In the third section, we test if these differences in wages are explained by differences in productivity. In the fourth section, we question the mechanisms that allow for the regional differences in productivity to be reflected in wages. Finaly, the fifth section concludes.

\section{Data}

The present study is based upon a unique combination of two large-scale data sets. The first, carried out by Statistics Belgium, is the 2003 Structure of Earnings Survey (SES). It covers Belgian firms employing at least 10 workers with economic activities within sections $\mathrm{C}$ to $\mathrm{K}$ of the Nace Rev.1 nomenclature. The survey contains a wealth of information, provided by the management of the establishments, both on the characteristics of the latter (e.g. region, industry, type of financial and economic control, size of the establishment) and on their workers (e.g. education, age, seniority, gross hourly wages, number of paid working hours, sex, type of employment contract, occupation). Therefore, it allows estimating regional wage differentials by taking into account compositions effects. Since the SES provides no financial information, it has been merged with the 2003 Structure of Business Survey (SBS). This is a firm-level survey, also conducted by Statistics Belgium, with a different coverage than the SES in that it includes neither the banking sector, nor the electricity sector, nor firms with less than 20 employees. The SBS provides firm-level information on value-added per employee, which will be used as a proxy for labour productivity. Since the dataset covers only firms whose employ salaried workers, the productivity is therefore only that of 
salaried workers and not of self-employed workers. Let us finally note that the results are not biased by the phenomenon of the commuters (which is important in Belgium) because the data are provided by the companies and thus reflect the productivity of the workers at their workplace.

For the results to be sufficiently representative, we only analyse the joint committees which count at least 5 local units ${ }^{11}$ in each region in the dataset. Only 25 joint committees (out of 83) are in this situation. If one excludes Brussels, the number of joint committees with at least 5 local units in both the Flemish and Walloon regions reaches 36. The difference comes mainly from joint committees from the manufacturing sector which are absent in the Brussels region. Considering that restricting the analysis to joint committees present in Brussels would make one miss a lot of information, we compare the regions two by two. The analysis is therefore based on 3 different samples that count for 25 joint committees for the Brussels-Wallonia comparison, 26 joint committees for the BrusselsFlanders comparison, and 36 joint committees for the Flanders-Wallonia comparison. After having eliminated the heads of companies (ISCO 1) who are not covered by collective agreements, and the observations with missing or abnormal values, the three analysed sub-samples account for $85.8 \%, 86.3 \%$ and $91.3 \%$ of the initial samples covering respectively Brussels and Wallonia, Brussels and Flanders, and Flanders and Wallonia.

\section{Are there differences in wages between regions?}

Without controlling for differences in characteristics between regions, the mean hourly wage $^{12}$ in Brussels is $8.2 \%$ higher than in Flanders and $11.1 \%$ than in Wallonia. The mean hourly wage is, in Flanders, $1.8 \%$ higher than in Wallonia. These differences in

\footnotetext{
${ }^{11}$ A local unit corresponds to all the establishments of a company situated in the same commune and coming from the same sector of activity.

${ }^{12}$ Gross hourly wage includes overtime paid, premiums for shift, night and/or week-end work, and regular bonuses. It does not include irregular payments which do not occur during each pay period, such as pay for holiday, $13^{\text {th }}$ month, profit-sharing, etc.
} 
wages can nonetheless be affected by differences in characteristics between the regions. ${ }^{13}$ In particular, employees in Brussels are on average more qualified than those that work in the other regions, which most likely comes from Brussels' status as a metropolis, capital of Belgium and seat of European institutions. Econometric estimations are thus necessary to isolate the impact of the regions from the effect of other variables. More precisely, we measure the regional wage differentials by estimating wage equations (an equation covering the population working in Brussels and in Flanders, an equation covering the population working in Wallonia and in Flanders and an equation covering the population working in Brussels and Wallonia) which contain controls for factors which intervene in the criteria determining the industry agreed wages (occupation, prior experience ${ }^{14}$, seniority in the company, type of contract, working hours, being working in a team or during night or weekend). The occupation variable is nonetheless not very disaggregated (9 functions for the workers and 12 for the employers) compared to many classifications of occupations in industries or firms. Consequently, it could be that our estimates are biased by the fact that the occupations are distributed differently in the three regions. In order to reduce this bias, we also control for the joint committee, the industry (NACE nomenclature -3 digits-), the gender, the level of education, the form of economic and financial control, and the size of the company. Moreover, we control for the fact that the employee works overtime. The results of these estimations are presented in the first column (model 1) in Table 1. Controlling for differences in characteristics, the differences between Flanders and Wallonia increases slightly (reaching $2.4 \%$ ) whilst the differential between Brussels and Wallonia falls to 2.6\% and the differential between Brussels and Flanders disappear completely. Most of the wage differential between Brussels and the two other regions thus seems to be explained by differences in characteristics between regions. ${ }^{15}$

\footnotetext{
13 See table in Appendix 2.

${ }^{14}$ Prior potential experience $=$ age - senority in the company - estimated number of years of schooling -6 .

15 The complete results of the wage equations are presented in appendix.
} 
Table 1: Regional Wage Differentials, All Joint Committees Taken Together

\begin{tabular}{|c|c|c|}
\hline & & \\
\hline Wage differential $^{\mathrm{a}}$ Flanders - Wallonia & & \\
\hline Wage differential ${ }^{\mathrm{a}}$ Brussels - Flanders & & \\
\hline Wage differential $^{\mathrm{a}}$ Brussels - Wallonia & $\begin{array}{c}2.6 \% * * * \\
(2.9)\end{array}$ & $\begin{array}{c}1.8 \% * * \\
(2.1)\end{array}$ \\
\hline Productivity in the company ${ }^{b}$ & no & yes \\
\hline \multicolumn{3}{|c|}{ 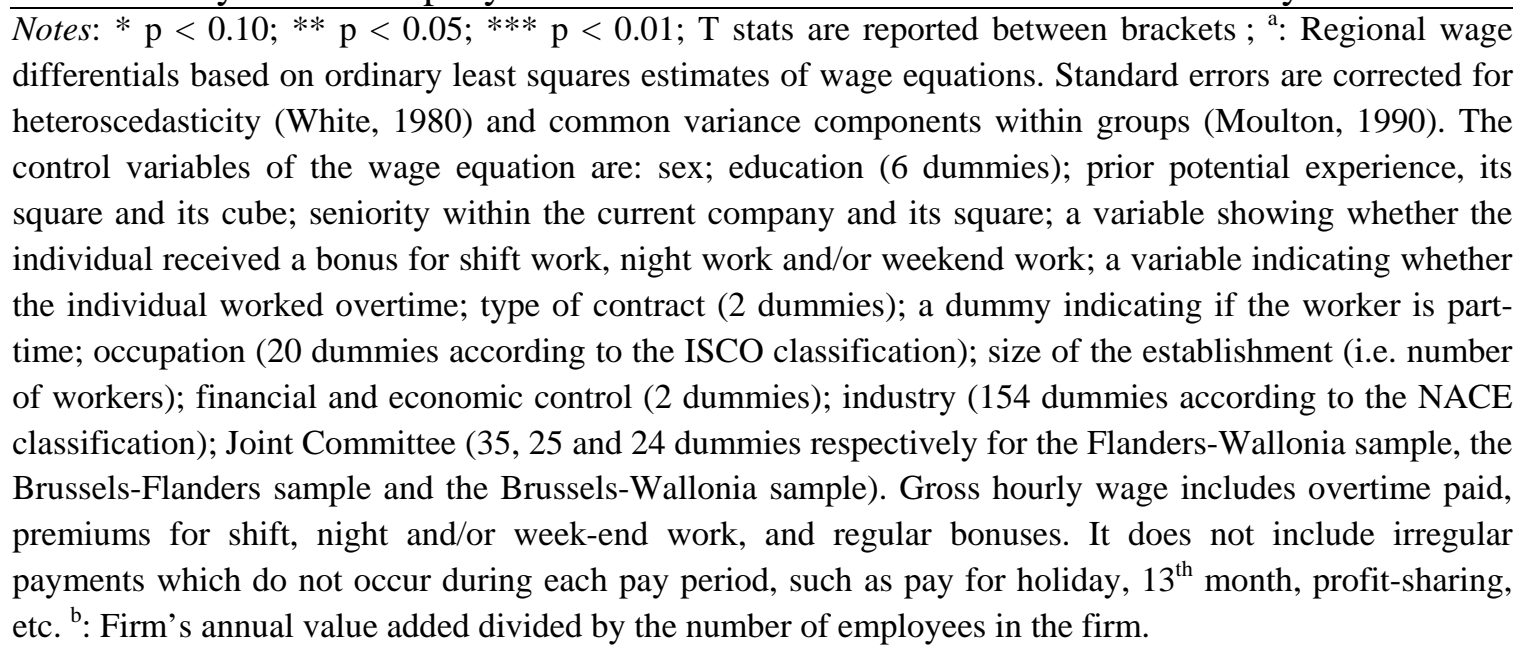 } \\
\hline
\end{tabular}

These results can nonetheless hide some disparities between joint committees. In order to verify this, we have estimated the wage differentials by joint committee. The choice of the joint committee is justified by the fact that this is the predominant level of bargaining in Belgium and that it is this level that could potentially be regionalised. Tables 2 to 4 synthesise the results. The complete denomination of the joint committees is given in the appendix. Nearly half of the Walloon workers ${ }^{16}$ from the sample work in a joint committee where there exists a significant statistical wage differential with Flanders

\footnotetext{
16 To be correct, they are "workers who are employed in Wallonia": the data coming from the workplace an not the home place.
} 
and/or with Brussels (see Table 2 and 3). In the majority of cases, wages are lower in Wallonia and the differentials are, on average, a bit more than $8 \%$. For the 3 joint committees where wages are higher in Wallonia (textile, cleaning, and big stores), the differentials are weaker and are around $4 \%$. Concerning the comparison between Brussels and Flanders, the proportion of employees who work in a joint committee where there exists a significant regional wage difference is smaller (31.2\% of Flemish workers and $21.9 \%$ of workers from Brussels). Again, wages are most often higher in Flanders. However, one can see a bigger symmetry in the differentials: they are around $8 \%$ both when wages are higher in Flanders and in Brussels. It seems therefore that the absence of wage differentials between Flanders and Brussels that was obtained for all joint committees taken together is due to the fact that the differentials within each joint committee compensate each other. One thus sees here the relevance to lead an analysis at the joint committee level rather than at the aggregate national level.

To summarize, it seems that the Belgian system of wage bargaining does not prevent having differences in wages between the regions, even if the situation varies according to the joint committee and the regions that are compared.

Table 2: Wage differentials between Flanders and Wallonia by joint committee

\begin{tabular}{lccc}
\hline & $\begin{array}{c}\text { Joint Committees } \\
\text { where wages are } \\
\text { higher in } \\
\text { Flanders than in } \\
\text { Wallonia } \\
(1)\end{array}$ & $\begin{array}{c}\text { Joint Committees } \\
\text { where wages are }^{\text {lower }} \text { in } \\
\text { Flanders than in } \\
\text { Wallonia } \\
(2)\end{array}$ & $\begin{array}{c}\text { All Joint } \\
\text { Committees with a } \\
\text { statistically } \\
\text { significant regional } \\
\text { wage differential } \\
(1+2)\end{array}$ \\
\hline Number of Joint Committees & 11 & 2 & 13 \\
(total in the sample = 36) & $43.6 \%$ & $5.6 \%$ & $49.2 \%$ \\
In \% of employees in Flanders & $41.0 \%$ & $3.4 \%$ & $44.4 \%$ \\
In \% of employees in Wallonia & & & \\
\hline Distribution of the regional & & & \\
wage differentials ${ }^{\mathrm{a}}$ : & $8.5 \%$ & $-3.8 \%$ & \\
Mean & $8.1 \%$ & $-3.8 \%$ & \\
Median & $4.1 \%$ & $1.3 \%$ & \\
Standard deviation & $3.5 \%{ }^{\mathrm{b}}$ & $-2.9 \%{ }^{\mathrm{d}}$ & \\
Minimum & $17.2 \%{ }^{\mathrm{c}}$ & $-4.7 \%{ }^{\mathrm{e}}$ & \\
Maximum & & & \\
\hline
\end{tabular}

Notes: Regional wage differentials are based on ordinary least squares estimates of wage equation (see notes of table 1 for more details); ${ }^{\text {a }}$ : Differentials statistically significant at the $10 \%$ level; ${ }^{\text {b }}:$ joint committee

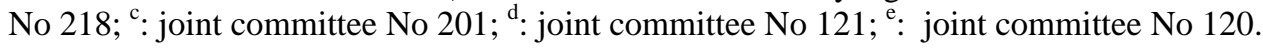


Table 3: Wage differentials between Brussels and Wallonia by joint committee

\begin{tabular}{|c|c|c|c|}
\hline & $\begin{array}{l}\text { Joint Committees } \\
\text { where wages are } \\
\text { higher }^{\mathrm{a}} \text { in } \\
\text { Brussels than in } \\
\text { Wallonia } \\
(1)\end{array}$ & $\begin{array}{l}\text { Joint Committees } \\
\text { where wages are } \\
\text { lower }^{\mathrm{a}} \text { in } \\
\text { Brussels than in } \\
\text { Wallonia } \\
(2)\end{array}$ & $\begin{array}{c}\text { All Joint } \\
\text { Committees with a } \\
\text { statistically } \\
\text { significant regional } \\
\text { wage differential } \\
(1+2) \\
\end{array}$ \\
\hline $\begin{array}{l}\text { Number of Joint Committees } \\
\text { (total in the sample }=25 \text { ) }\end{array}$ & 8 & 2 & 10 \\
\hline In \% of employees in Wallonia & $41.8 \%$ & $4.7 \%$ & $46.5 \%$ \\
\hline In \% of employees in Brussels & $64.5 \%$ & $5.4 \%$ & $69.9 \%$ \\
\hline \multicolumn{4}{|l|}{$\begin{array}{l}\text { Distribution of the regional } \\
\text { wage differentials }{ }^{\mathrm{a}} \text { : }\end{array}$} \\
\hline Mean & $8.3 \%$ & $-4.3 \%$ & \\
\hline Median & $8.1 \%$ & $-4.3 \%$ & \\
\hline Standard deviation & $3.4 \%$ & $1.9 \%$ & \\
\hline Minimum & $5.1 \%{ }^{\mathrm{b}}$ & $-3.0 \%{ }^{\mathrm{d}}$ & \\
\hline Maximum & $14.7 \%^{\mathrm{c}}$ & $-5.6 \%{ }^{\mathrm{e}}$ & \\
\hline
\end{tabular}

Table 4: Wage differentials between Brussels and Flanders by joint committee

\begin{tabular}{|c|c|c|c|}
\hline & $\begin{array}{l}\text { Joint Committees } \\
\text { where wages are } \\
\text { higher }^{\mathrm{a}} \text { in } \\
\text { Brussels than in } \\
\text { Flanders } \\
\text { (1) }\end{array}$ & $\begin{array}{l}\text { Joint Committees } \\
\text { where wages are } \\
\text { lower }^{\mathrm{a}} \text { in } \\
\text { Brussels than in } \\
\text { Flanders } \\
(2)\end{array}$ & $\begin{array}{c}\text { All Joint } \\
\text { Committees with a } \\
\text { statistically } \\
\text { significant regional } \\
\text { wage differential } \\
(1+2)\end{array}$ \\
\hline $\begin{array}{l}\text { Number of Joint Committees } \\
\text { (total in the sample }=26 \text { ) }\end{array}$ & 3 & 8 & 11 \\
\hline In \% of employees in Flanders & $7.0 \%$ & $24.2 \%$ & $31.2 \%$ \\
\hline In \% of employees in Brussels & $6.9 \%$ & $15.0 \%$ & $21.9 \%$ \\
\hline \multicolumn{4}{|l|}{$\begin{array}{l}\text { Distribution of the regional } \\
\text { wage differentials }{ }^{\text {a }} \text { : }\end{array}$} \\
\hline Mean & $7.5 \%$ & $-7.8 \%$ & \\
\hline Median & $7.8 \%$ & $-8.1 \%$ & \\
\hline Standard deviation & $1.6 \%$ & $1.3 \%$ & \\
\hline Minimum & $5.8 \%{ }^{\mathrm{b}}$ & $-5.6 \%{ }^{d}$ & \\
\hline Maximum & $9.1 \%^{\mathrm{c}}$ & $-9.5 \%^{\mathrm{e}}$ & \\
\hline
\end{tabular}

Notes: Regional wage differentials are based on ordinary least squares estimates of wage equation (see notes of table 1 for more details); ${ }^{\mathrm{a}}$ : Differentials statistically significant at the $10 \%$ level; ${ }^{\text {b }}$ : joint committee

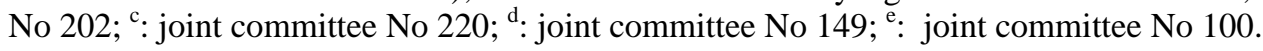




\section{Are the regional wage differentials explained by regional differences in productivity?}

To answer this question, we, first, introduce the average firm's productivity in the wage equations in order to see if regional wage differentials vary in comparison to the basic specification. The wage differentials estimated via this specification are presented in the second row (model 2) in Table 1. The introduction of a firm's productivity in the wage equations makes the wage differentials between Flanders and Wallonia go from $2.4 \%$ to $1.9 \%$ and the differentials between Brussels and Wallonia go from $2.6 \%$ to $1.8 \%$. The wage differential between Brussels and Flanders does not change when we control for firm's productivity. In other words, part of the wage differentials between Wallonia and the two other regions seems to be explained by differences in productivity between the firms situated in the different regions. One still needs to consider these results with prudence given the fact that the differences between the differentials of the two models are not statistically significant. ${ }^{17}$

This first result in mind, we want to see if the regional differentials in wage and productivity for each joint committee are correlated. Using the results from the 3 samples, the analysis is based on 87 wage differentials and 87 productivity differentials. ${ }^{18}$ Graphic 1 puts in relation the regional wage and productivity differentials within each joint committee. Each point on the graphic represents one joint committee. Most of the joint committees are represented several times as they are present in more than one sample. As the graphic shows, wage and productivity differentials seem to be positively correlated. This is confirmed by the coefficient of correlation between the two differentials which is 0.38 and significant at $1 \%$.

\footnotetext{
${ }^{17}$ In other terms, one cannot exclude the hypothesis in which the differentials of the two models are identical.

18 The methodology for the calculation of wage differentials per joint committee is presented in appendix 4. The wage and productivity differentials per joint committee are presented in appendix 5.
} 


\section{Graphic 1: Regional Differentials in Wage and Productivity by Joint Committee}

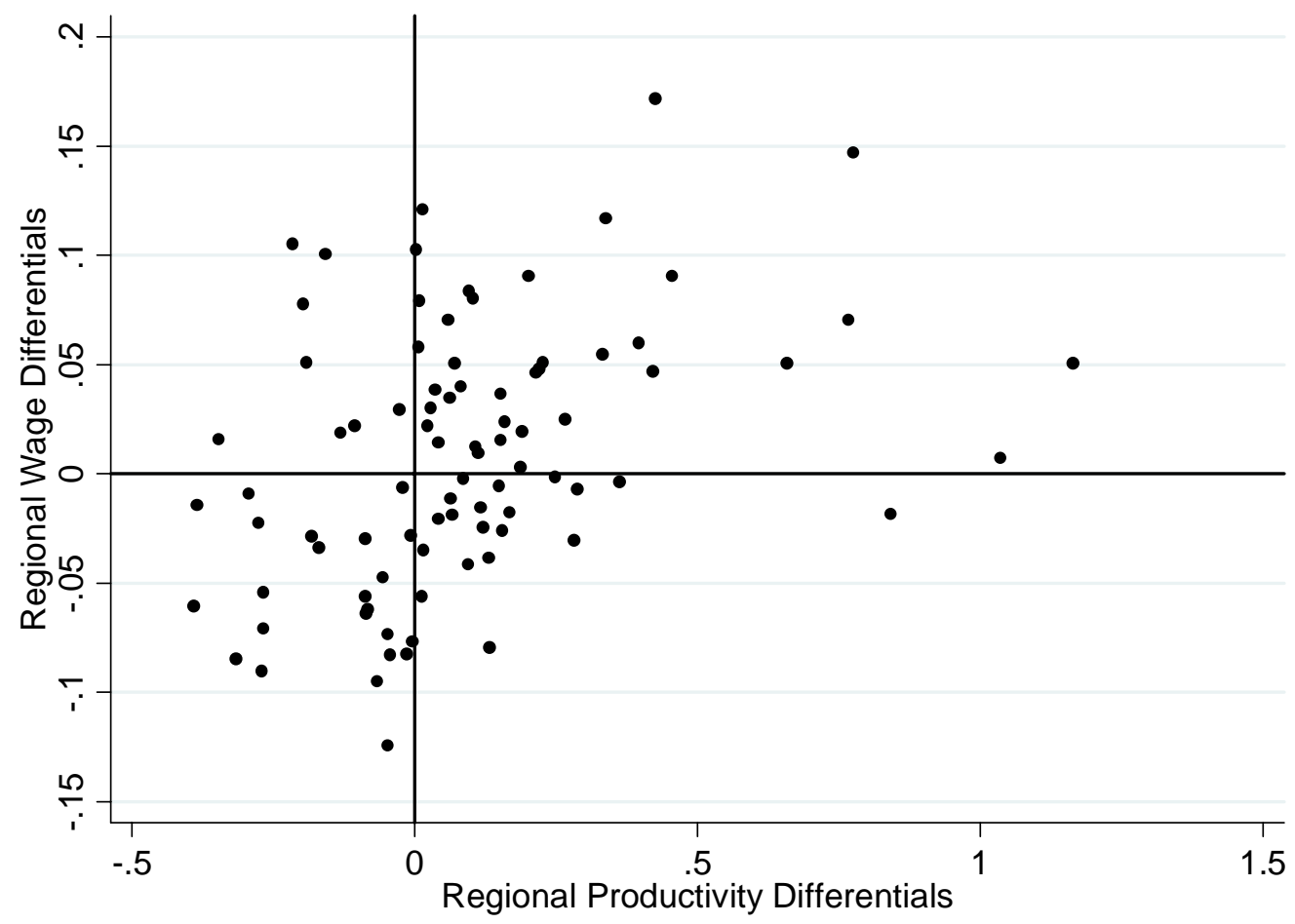

Notes: Regional wage differentials are estimated using the regional dummy variables in the different wage equations (estimated by OLS). The per capita firm's value added serves as proxy to the productivity level.

\section{What mechanism allows for regional productivity differentials to be reflected in} wages?

In addition to the inter-professional and industry bargaining levels that are national, two other levels of bargaining exist in Belgium. First, some joint committees are subdivided into regional sub-joint committees. Secondly, industry agreements can be completed through bargaining at the company level. The existence of regional wage differentials could therefore be explained by these two mechanisms.

Can bargaining at the company level explain how regional differences in productivity lead to regional wage differentials? In order to verify this hypothesis, we compare the relation between the regional wage and productivity differentials in the centralised joint committees and in the decentralised joint committees. We consider a joint committee to 
be decentralised if the percentage of wages covered by firm-level collective agreement is superior to the median, which is to say $28 \%$. If the hypothesis is correct, the relation between productivity differentials and wage differentials should be higher in decentralised joint committees, meaning where the level of the company has an important weight in determining wages. ${ }^{17}$ Our results show that the correlation between the two differentials is 0.50 and is significant at $1 \%$ for the decentralised joint committees, whilst it is only 0.30 and significant to the $5 \%$ for the centralised joint committees. Graphics 2 and 3 illustrate these results.

\section{Graphic 2: Regional Differential in Wage and Productivity by Joint Committee, Decentralised Joint Committees.}

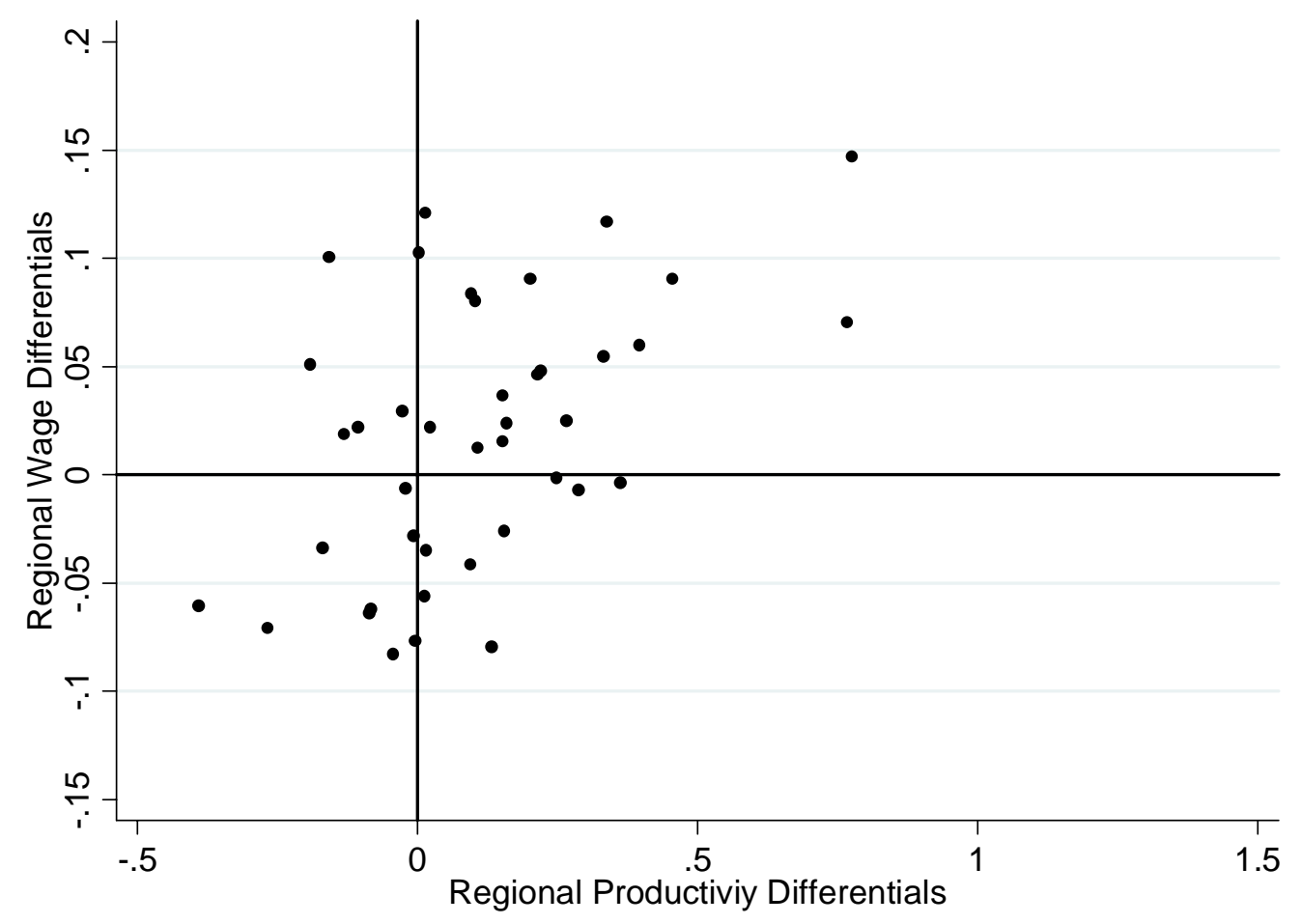

Notes: Regional wage differentials are estimated using the regional dummy variables in the different wage equations (estimated by OLS). The per capita firm's value added serves as proxy to the productivity level.

\footnotetext{
${ }^{17}$ One must be aware that we cannot distinguish if the decentralization concerns wage levels (classification of functions and/or determination of regular bonuses), wage increases or both. The information from the database indicates only the eventual presence of a company-specific agreement, which could be carried on wages or on work time.
} 


\section{Graphic 3: Regional Differential in Wage and Productivity by Joint Committee Centralised Joint Committees.}

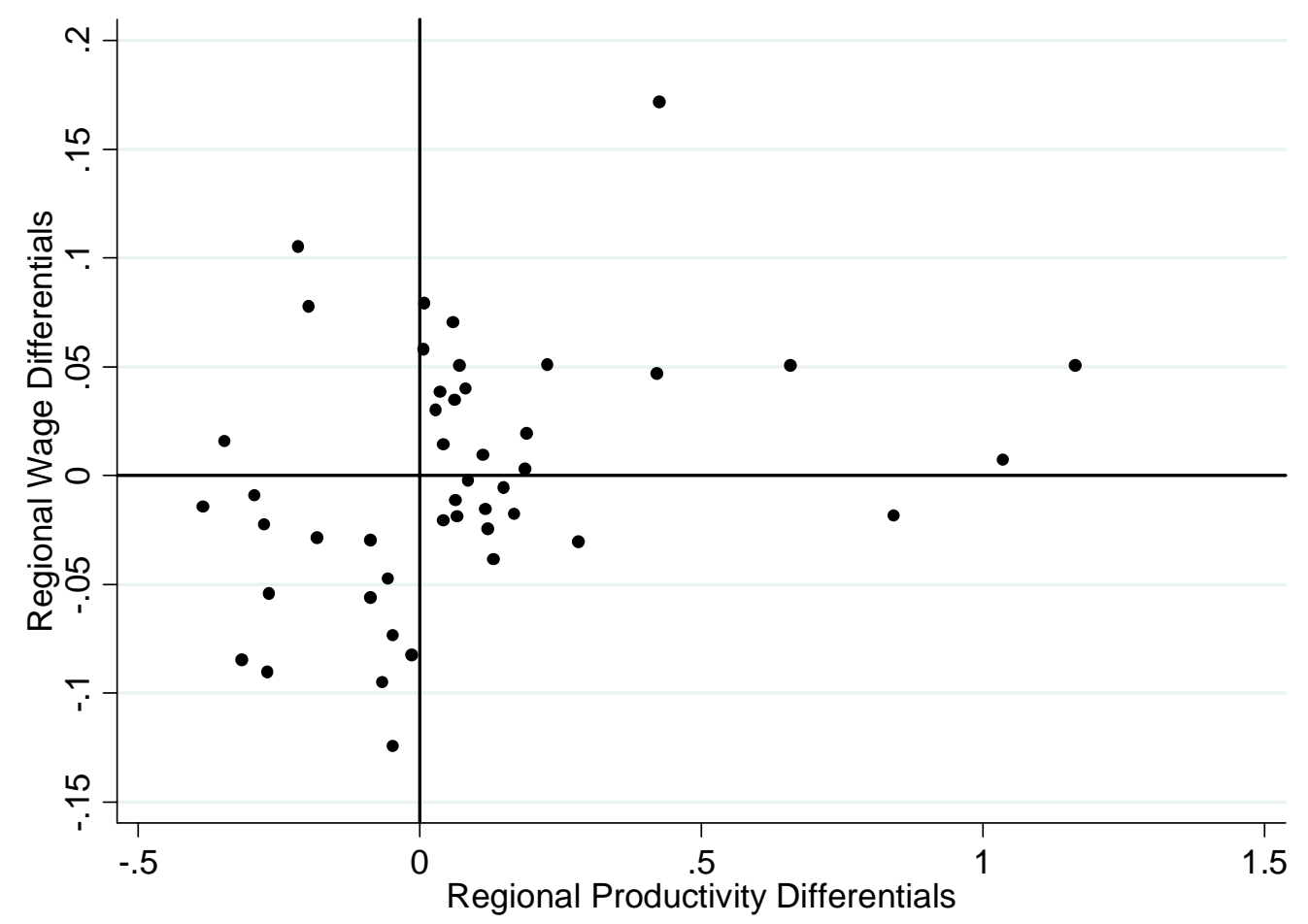

Notes: Regional wage differentials are estimated using the regional dummy variables in the different wage equations (estimated by OLS). The per capita firm’s value added serves as proxy to the productivity level.

The comparison of the two graphics shows a stronger relation between the wage and productivity differentials for decentralised joint committees then for centralised ones, where relatively high productivity differentials can be associated to relatively low wage differentials. These results seem to validate the hypothesis that the presence of companyspecific agreement may allow wages to adapt to regional productivity differentials.

Nonetheless, it is possible that the subdivision of joint committees into regional sub-joint committees also allows wages to adapt to regional differentials in productivity. Only 3 joint committees are subdivided into regional sub-joint committees in our sample. This is the case of the Joint Committee for the manufacture of metal, mechanical and electrical products 
(111), the Joint Committee for white collar workers employed in the manufacture of metal products (209) and the Joint Committee of urban and regional transport (328). One should note that this subdivision is not necessarily done according to the region. The metallic production sector (CP 111.1 and 111.2), for example, is divided into 10 regional committees. ${ }^{19}$ The correlation between regional wage and productivity differentials for these joint committees is 0.76 and is significant at $5 \%$. It seems therefore that the subdivision of joint committees into regional sub-joint committees also allows wages to adapt to regional differentials in productivity. One must, nonetheless, consider this result with prudence since the number of observations used in this calculation is relatively low. ${ }^{20}$ Considering that these 3 joint committees are classified in the decentralised joint committee category ${ }^{21}$, one can ask if the results relative to the degree of centralisation are not affected by the local subdivision of these joint committees. In order to verify this, we calculate the coefficient of correlation for the decentralised joint committees by excluding the 3 regional subdivided joint committees. The correlation diminishes very slightly from 0.50 to 0.49 and is still significant at $1 \%$, which confirms that companyspecific agreements equally allow for regional productivity differentials to be reflected in wage differentials.

\section{Conclusion}

Within the framework of the debate over the relationship between the structure of wage bargaining and economic performances in Europe, the question concerning the regional dimension returns in a recurring way. The discussion often relates, in particular, to the capacity of wage-setting systems to take into account the important economic disparities between regions.

\footnotetext{
19 Brabant, Flandre occidentale, Flandre orientale, Anvers-Limbourg, Saint-Nicolas, Charleroi-Namur, Liège-Luxembourg, Centre, Tournais, et Mons-Borinage.

${ }^{20}$ Considering the fact that these 3 joint committees are presented in the 3 samples, this correlation is based on 9 observations.

${ }^{21} 47 \%$, 38\% and 64\% of employees are covered by a company-specific agreement respectively for the joint committees 111,209 and 328.
} 
In Belgium, the regionalisation of wage bargaining is at the heart of current negotiations relative to a de-federalisation of employment policy. The partisans for the regionalisation of wage bargaining argue that the differences in productivity between regions cannot be reflected in a formation of wages at the federal level. They add that a negotiation at the Wallonia level would be more sensitive to unemployment and would thus involve lower wages for this region.

In this article we have put forward the fact that an important proportion of Belgian employees are covered by joint committees which allow significant regional wage differentials. In addition, regional wage differentials and productivity differentials by joint committee are strongly correlated. These two results permit to conclude that the federal characteristic of the Belgian system of wage bargaining allow wages to adapt to differences in regional productivity. It could be argue, however, that this level of flexibility is not sufficient, in the sense that it does not remove the regional differences in terms of unit labour cost. Our results do not allow us to answer this question. Nevertheless our study has highlighted the mechanisms that allow wages to adapt to regional productivity. We observe that the correlation between regional wage differentials and regional productivity differentials is higher in decentralised joint commissions (whereby company-specific agreement has a significant impact on the wage setting) and in joint committees subdivided in regional sub-joint committees. Therefore, it seems that it is the possibility to negotiate wages at the company level and the existence of regional sub-joint committees that allow wages to adapt to the regional productivity differentials.

If wages are not enough sensitive to the local specificities, these two mechanisms could be extended. This solution has the advantage of avoiding increasing administrative complexities in joint committees where a more important wage differential is not necessary. Moreover, the decision to increase the weight of company-specific agreements or to subdivide joint committees is taken by the national joint committees, composed of those close to the reality on the field. In addition, these mechanisms allow not only taking into account differences between regions but equally differences between provinces, 
labour pools or companies. Lastly, as already pointed by several authors, regionalisation of wage bargaining could create a higher increase in wages than in the current national system, and could open the path to the regionalisation of the social security. In conclusion, the current system already contains the mechanisms that allow for regional differences in productivity to be reflected in wages. It is therefore not certain that a regionalisation of the wage setting system is necessary.

Finally, let us note that increasing regional wage differentials will increase wage inequalities but the impact on unemployment is unknown Future research should focus at the regional level on the impact of an increasing wage dispersion on the employment level. Nevertheless, other paths should also be followed in order to increase the level of employment, notably investment in education, training and R\&D, or reductions of social security contributions aimed at low-skilled workers. 


\section{References}

BANDE, Roberto, Melchor FERNÁNDEZ and Víctor MONTUEGA, 2008, « Regional unemployment in Spain: Disparities, business cycle and wage setting ", Labour Economics, 15(2008), 885-914.

BOGAERT, Henri, 2008, «Formation des salaires et chômage régional en Belgique : un regard macro-économique », Federal Plan Bureau, Working Paper 3-08.

DAVIES, Sara and Martin HALLET, 2001, « Policy responses to regional unemployment: Lessons from Germany, Spain and Italy », Economic Papers No. 161, Brussels: European Commission.

DEJEMEPPE, Muriel and Bruno VAN DER LINDEN, 2006, « Actions du Plan Marshall sur le marché du travail wallon », Regards Economiques, Avril 2006, № 40.

DELL'ARINGA, Carlo and Laura PAGANI, 2005, « Regional Wage Differentials and Collective Bargaining in Italy », Rivista Internazionale di Scienze Sociali, 113 (2), pp. 267-287.

DESCHAMPS, Robert, 2003, « Faut-il régionaliser la négociation salariale ? », Reflets et Perspectives de la Vie Economique, Tome XLII, 2003, N 4, pp. 71-80.

EIRO, 1998, « Union confederations sign agreement on supporting job creation in the South », http://www.eurofound.europa.eu/eiro/1998/01/feature/it9801219f.htm

JOSKIN, A., N. CHAIDRON, M. MIGNOLET and M-E MULQUIN, 2008, « Salaires et coût du travail : constat émergeant des données sectorielles régionales », CERPE, Cahiers de recherche, Série Politique Economique, n²3 - 2008/02.

MOULTON, Brent R., 1990, «An Illustration of a Pitfall in Estimating the Effects of Aggregate Variables on Micro Unit. » Review of Economics and Statistics, Vol. 72, No. 2, pp. 334-338. 
OECD, 2006, Employment Outlook, Paris: OECD.

PENCH, Lucio R., Paolo SESTITO, and Elisabetta FRONTINI, 1999, « Some Unpleasant Arithmetics of Regional Unemployment in the EU. Are there Any Lessons for EMU ? », Economic Papers No. 134, Brussels: European Commission.

PLASMAN, Robert, Michael RUSINEK and Ilan TOJEROW, 2007, « La régionalisation de la négociation salariale en Belgique: vraie nécessité ou faux débat ? », Reflets et Perspectives de la Vie Economique, Tome XLVI, 2007, № 2-3, pp. 65-74.

SCHNABEL, Claus , 1999, «Collective Bargaining under Stress: Decentralisation and Opening Clauses in Germany », Communication présentée à la conférence « Controlled Decentralisation of Wage Bargaining - The German Experience with the Exit Clause », organisée par la Fondazione Rodolfo Debenedetti et la Banca d'Italia, Rome.

SIMÓN, Hipólito J., Raúl RAMOS, and Esteban SANROMÁ, 2006, « Collective Bargaining and Regional Wage Differences in Spain: An Empirical Analysis », Applied Economics, 38, pp. 1749-1760.

VAMVAKIDIS, Athanasios, 2008, « Regional Wage Differentiation and Wage Bargaining Systems in the EU », IMF Working Paper No. 08/43, Washington: IMF.

VERLY, Jean, 2003, «La décentralisation des relations collectives de travail », Reflets et Perspectives de la Vie Economique, Tome XLII, 2003, № 4, pp. 23-34.

WHITE, H., 1980, « A Heteroscedasticity-Consistent Covariance Matrix Estimator and a Direct Test for Heteroscedasticity », Econometrica, Vol. 48, pp.817-38. 


\section{Appendix 1: Description of the Joint Committees analysed}

\begin{tabular}{|c|c|}
\hline $\begin{array}{l}\text { No of the } \\
\text { Joint } \\
\text { Committee }\end{array}$ & Name of the Joint Committee \\
\hline 100 & Auxiliary joint committee for blue collar workers \\
\hline 105 & Joint committee for the manufacture of non ferrous metals \\
\hline 109 & Joint Committee for the clothing and apparel industries \\
\hline 111 & Joint Committee for the manufacture of metal, mechanical and electrical products \\
\hline 112 & Joint Committee for garage enterprises \\
\hline 115 & Joint Committee for the glass industry \\
\hline 116 & Joint Committee for the chemical industry \\
\hline 118 & Joint Committee for the food industry \\
\hline 119 & Joint Committee for the trade of food \\
\hline 120 & Joint Committee for the textile and hosiery industries \\
\hline 121 & Joint Committee for the cleaning industry \\
\hline 124 & Joint Committee for the building industry \\
\hline 126 & Joint Committee for the manufacture of furniture and wood products \\
\hline 129 & Joint Committee for the manufacture of pulp and paper \\
\hline 130 & Joint Committee for printing, graphic arts and newspapers \\
\hline 136 & Joint Committee for the manufacture of pulp and paper products \\
\hline 140 & Joint Committee for transport and logistics \\
\hline 142 & Joint Committee for waste reprocessing \\
\hline 149 & $\begin{array}{l}\text { Joint Committee of sectors connected the manufacture of metal, mechanical and electrical } \\
\text { products }\end{array}$ \\
\hline 201 & Joint Committee for independent retailing \\
\hline 202 & Joint Committee for white collar workers employed in food retailing \\
\hline 207 & Joint Committee for white collar workers employed in the chemical industry \\
\hline 209 & Joint Committee for white collar workers employed in the manufacture of metal products \\
\hline 210 & Joint Committee for white collar workers employed in the steel industry \\
\hline 211 & Joint Committee for white collar workers employed in the oil industry \\
\hline 214 & Joint Committee for white collar workers employed in the textile and hosiery industries \\
\hline 215 & Joint Committee for white collar workers employed in the clothing and apparel industries \\
\hline 218 & National Auxiliary joint committee for white collar workers \\
\hline 220 & Joint Committee for white collar workers employed in the food industry \\
\hline 221 & Joint Committee for white collar workers employed in the paper industry \\
\hline 222 & Joint Committee for white collar workers employed in the manufacture of pulp and paper \\
\hline 224 & Joint Committee for white collar workers employed in the manufacture of non ferrous metals \\
\hline 226 & $\begin{array}{l}\text { Joint Committee for white collar workers employed in international trade, transport and } \\
\text { logistics }\end{array}$ \\
\hline 302 & Joint Committee of the hotel industry \\
\hline 307 & Joint Committee for brokerage firms and et insurance agencies \\
\hline 311 & Joint Committee of large retail firms \\
\hline 312 & Joint Committee of department stores \\
\hline 313 & Joint Committee for medicine shops \\
\hline 328 & Joint Committee of urban and regional transport \\
\hline
\end{tabular}

Source: SPF Emploi, Travail et Concertation sociale. 


\begin{tabular}{|c|c|c|c|}
\hline & Brussels & Flanders & Wallonia \\
\hline Gross hourly wages (EUR) & 14.4 & 13.2 & 13.0 \\
\hline Value added-per-worker (EUR) & 91990.9 & 62302.0 & 56082.6 \\
\hline \multicolumn{4}{|l|}{ Worker's characteristics } \\
\hline Female & $40.9 \%$ & $36.0 \%$ & $33.8 \%$ \\
\hline Prior experience (years) & 11.3 & 12.2 & 12.2 \\
\hline \multicolumn{4}{|l|}{ Education: } \\
\hline Primary or no degree & $5.4 \%$ & $8.1 \%$ & $9.6 \%$ \\
\hline Lower secondary & $22.5 \%$ & $26.5 \%$ & $29.2 \%$ \\
\hline General upper secondary & $20.5 \%$ & $22.5 \%$ & $19.3 \%$ \\
\hline Technical/Artistic/Prof. upper secondary & $14.0 \%$ & $20.5 \%$ & $21.3 \%$ \\
\hline Higher non university short type, higher artistic training & $21.5 \%$ & $15.7 \%$ & $13.9 \%$ \\
\hline University and non-university higher education, long type & $14.9 \%$ & $6.4 \%$ & $6.2 \%$ \\
\hline Post-graduate & $0.4 \%$ & $0.2 \%$ & $0.3 \%$ \\
\hline \multicolumn{4}{|l|}{ Job's characteristics } \\
\hline Seniority in the company (years) & 7.8 & 7.8 & 8.5 \\
\hline Part-time & $16.0 \%$ & $17.2 \%$ & $15.1 \%$ \\
\hline Working in Shift, or During Night or Weekend & $8.5 \%$ & $12.9 \%$ & $16.9 \%$ \\
\hline Working overtime & $2.7 \%$ & $2.5 \%$ & $2.6 \%$ \\
\hline \multicolumn{4}{|l|}{ Type of contract: } \\
\hline Unlimited-term employment contract & $94.9 \%$ & $96.2 \%$ & $94.6 \%$ \\
\hline Limited-term employment contract & $4.8 \%$ & $3.3 \%$ & $4.5 \%$ \\
\hline Other employment contract & $0.4 \%$ & $0.4 \%$ & $0.8 \%$ \\
\hline \multicolumn{4}{|l|}{ Occupation (ISCO 1 digit): } \\
\hline Professionals & $23.1 \%$ & $11.0 \%$ & $10.0 \%$ \\
\hline Technicians and associate professionals & $12.0 \%$ & $9.7 \%$ & $10.2 \%$ \\
\hline Clerks & $26.4 \%$ & $19.8 \%$ & $19.1 \%$ \\
\hline Service workers and shop and market sales workers & $13.0 \%$ & $10.0 \%$ & $9.8 \%$ \\
\hline Craft and related trade workers & $10.6 \%$ & $20.2 \%$ & $24.3 \%$ \\
\hline Plant and machine operators and assemblers & $7.6 \%$ & $19.6 \%$ & $15.5 \%$ \\
\hline Elementary occupations & $7.4 \%$ & $9.7 \%$ & $11.1 \%$ \\
\hline \multicolumn{4}{|l|}{ Firm's characteristics } \\
\hline Size of the establishment (number of employees) & 299.9 & 304.4 & 180.2 \\
\hline \multicolumn{4}{|l|}{ Form of Economic and Financial control: } \\
\hline $100 \%$ private & $94.2 \%$ & $97.6 \%$ & $96.2 \%$ \\
\hline Partly State owned & $0.1 \%$ & $0.8 \%$ & $0.4 \%$ \\
\hline Other & $5.7 \%$ & $1.6 \%$ & $3.4 \%$ \\
\hline
\end{tabular}


Mining and quarrying

Manufacturing

Construction

Wholesale and retail trade; Repair of motor vehicles, motorcycles and personal and household goods

Hotels and restaurants

Transport, storage and communication

Financial intermediation

Real estate, renting and business activities

$\begin{array}{ccc}0.0 \% & 0.0 \% & 0.1 \% \\ 15.8 \% & 38.3 \% & 36.7 \% \\ 5.6 \% & 8.9 \% & 11.3 \% \\ 28.9 \% & 21.0 \% & 23.5 \% \\ 6.8 \% & 3.1 \% & 3.0 \% \\ 10.7 \% & 10.1 \% & 9.3 \% \\ 2.2 \% & 0.4 \% & 0.5 \% \\ 29.9 \% & 18.3 \% & 15.7 \%\end{array}$

Note : means computed with sample weights 


\section{Appendix 3: Wage Equations for different samples}

\section{Brussels + Flanders} sample $^{\mathrm{a}}$

\section{Region of the establishment}

Brussels

Flanders

Wallonia

\section{Worker's characteristics}

Female

Prior experience:

Simple

Squared $/ 10^{2}$

Cubed $/ 10^{4}$

Education:

Primary or no degree

Lower secondary

General upper secondary

Technical/Artistic/Prof. upper secondary

Higher non university short type, higher artistic training

University and non-university higher education, long type

Post-graduate

\section{Job's characteristics}

Seniority in the company:

Simple

Squared $/ 10^{2}$

$$
\begin{gathered}
-0.009 \\
(0.007)
\end{gathered}
$$

Reference

n.a.

$$
\begin{gathered}
-0.108 * * * \\
(0.005)
\end{gathered}
$$

$0.018 * * *$

(0.001)

$-0.055^{* * *}$

(0.006)

$0.057 * * *$

(0.010)
Brussels + Wallonia sample $^{b}$

$0.017^{* *}$
$(0.009)$

n.a.

Reference
Flanders + Wallonia sample $^{c}$

n.a.

$0.019 * * *$

(0.005)

Reference
$-0.075^{* * *}$

(0.006)

$0.020 * * *$

(0.002)

$-0.064 * * *$

(0.009)

$0.074 * * *$

(0.013)

Reference

$0.021^{* * *}$
$(0.007)$
$0.067 * * *$
$(0.008)$
$0.076^{* * *}$
$(0.008)$
$0.145^{* * *}$
$(0.010)$
$0.276^{* * *}$
$(0.012)$
$0.524 * * *$
$(0.053)$

$0.021^{* * *}$

$0.067 * * *$

(0.008)

(0.008)

$0.145^{* * *}$

(0.010)

$0.276 * * *$

$0.524 * * *$

(0.053)
0.006

(0.010)

$0.048 * * *$

(0.012)

$0.077^{* * *}$

(0.011)

$0.148^{* * *}$

(0.014)

$0.278 * * *$

(0.018)

$0.480 * * *$

(0.041)
$-0.121 * * *$

(0.004)

$0.016 * * *$

(0.001)

$-0.046 * * *$

(0.005)

0.050***

(0.009) 


$\begin{array}{lccc} & (0.002) & (0.003) & (0.002) \\ \text { Working in Shift, or During } & 0.047^{* * *} & 0.067^{* * *} & 0.043^{* * *} \\ \text { Night or Weekend } & (0.007) & (0.009) & (0.006) \\ \text { Working overtime } & 0.032^{* * *} & 0.037^{* * *} & 0.018^{* *} \\ & (0.009) & (0.012) & (0.008) \\ \text { Part time } & -0.003 & -0.006 & -0.002 \\ & (0.005) & (0.007) & (0.005)\end{array}$

Type of contract:

Unlimited-term employment contract
Limited-term employment contract

Other employment contract

\section{Firm's characteristics}

Value added-per-worker (ln)

Size of the establishment ${ }^{\mathrm{e}}(\ln )$

Form of economic and financial control: 100\% Private

\begin{tabular}{lccc} 
Partly State owned & -0.031 & $-0.081^{*}$ & -0.018 \\
& $(0.040)$ & $(0.043)$ & $(0.040)$ \\
Other & 0.002 & -0.019 & 0.011 \\
& $(0.018)$ & $(0.027)$ & $(0.018)$ \\
\hline $\mathrm{R}^{2}$ & 0.58 & 0.60 & 0.56 \\
F stat & $5346.7^{* * *}$ & $10703.0^{* * *}$ & $72.5^{* * *}$ \\
Number of observations & 49708 & 26445 & 58427
\end{tabular}

Notes : * $\mathrm{p}<0.10$; ${ }^{* *} \mathrm{p}<0.05$; ${ }^{* *} \mathrm{p}<0.01$; $\mathrm{T}$ stats are reported between brackets ; Standard errors are corrected for heteroscedasticity (White, 1980) and common variance components within groups (Moulton, 1990). ${ }^{\text {a }}$ : covers the joint committees No 100, 111, 112, 116, 118, 119, 121, 124, 126, 130, 136, 140, 149, 201, 202, 207, 209, 211, 218, 220, 226, 302, 311, 312, 313 and 328; ' : idem except No 211; ': idem plus No $105,109,115,120,129,142,214,215,222,224$ and 307 ; ${ }^{d}$ : age minus seniority in the company minus estimated number of years of schooling minus 6; e: Number of employees; The wage equation also contains controls for the occupation (20 dummies according to the ISCO classification); the industry (154 dummies according to the NACE classification) and the joint committee (35, 25 and 24 dummies respectively for the Flanders-Wallonia sample, the Brussels-Flanders sample and the Brussels-Wallonia sample). Gross hourly wage includes overtime paid, premiums for shift, night and/or week-end work, and regular bonuses. It does not include irregular payments which do not occur during each pay period, such as pay for holiday, $13^{\text {th }}$ month, profit-sharing, etc. 


\section{Appendix 4: Methodology used to estimate the regional wage differentials by joint committee:}

In the first stage, we estimate the following wage equation by ordinary least squares, correcting standard errors for heteroscedasticity (White, 1980) and for common variance components within groups (Moulton,1990):

$$
w_{i}=\alpha+\beta \operatorname{Re} \text { gion }_{i}+\sum_{j}^{J} \gamma_{j} J C_{j, i}+\sum_{j}^{J} \delta_{j}\left(\operatorname{Region}_{i} * J C_{j, i}\right)+\sum_{k}^{K} \theta_{k} X_{k, i}
$$

where $\mathrm{w}$ is the logarithm of the gross hourly wages of October 2003, which includes overtime paid, premiums for shift, night and/or week-end work, and regular bonuses and does not include irregular payments which do not occur during each pay period, such as pay for holiday, $13^{\text {th }}$ month, profit-sharing, etc ; Region is a dummy variable equal to 1 if the individual works in Brussels and 0 if he works in Wallonia when using the sample covering Brussels and Wallonia, 1 if the individual works in Brussels and 0 if he works in Flanders when using the sample covering Brussels and Flanders, and 1 if the worker works in Flanders and 0 if he works in Wallonia when using the sample covering Flanders and Wallonia; JCj are dummy variables indicating to which joint committee the individual belongs. For the sample covering Brussels and Wallonia, they are joint committees number 100, 111, 112, 116, 118, 119, 121, 124, 126, 130, 136, 140, 149, 201, 202, 207, 209, 211, 218, 220, 226, 302, 311, 312, 313 et 328. For the sample covering Brussels and Flanders, this is the same except the joint committee 211. For the sample covering Flanders and Wallonia, there is also the joint committees number 105, 109, 115, $120,129,142,214,215,222,224$, et 307 ; Finally $X_{k}$ are the control variables, namely sex; education (6 dummies); prior potential experience, its square and its cube; tenure within the current company and its square; a variable showing whether the individual received a bonus for shift work, night work and/or weekend work; a variable indicating whether the individual worked overtime; type of contract (2 dummies); a dummy indicating if the worker is part-time; occupation (20 dummies according to the ISCO classification); size of the establishment (i.e. number of workers); financial and economic control (2 dummies); industry (154 dummies according to the NACE classification);

The regional wage differential in the joint committee No $\mathrm{j}$ is given by: 
$e^{\beta+\delta_{j}}-1$

As an illustration, we estimate the wage differential between Flanders and Wallonia for the joint committee No 201, hence using the sample covering Flanders and Wallonia.

The mean logarithm of the gross hourly wages of individuals working in Flanders and belonging to the joint committee No 201 is given by:

$E\left(w_{i} \mid\right.$ Flanders \& $\left.J C_{201}\right)=\alpha+\beta+\gamma_{201}+\delta_{201}+\sum_{k}^{K} \theta_{k} X_{k, i}$

The mean logarithm of the gross hourly wages of individuals working in Wallonia and belonging to the joint committee No 201 is given by:

$E\left(w_{i} \mid\right.$ Wallonia $\left.\& J C_{201}\right)=\alpha+\gamma_{201}+\sum_{k}^{K} \theta_{k} X_{k, i}$

The difference in logarithm of gross hourly wages between Flanders and Wallonia in the joint committee No 201 is given by the difference between equation 3 and equation 4:

$E\left(w_{i} \mid\right.$ Flanders \& $\left.J C_{201}\right)-E\left(w_{i} \mid\right.$ Wallonia $\left.\& J C_{201}\right)=\beta+\delta_{201}$

Finally, the wage differential (in \%) is given by :

$e^{\beta+\delta_{201}}-1$

All the regional wage differentials by joint committees are presented in the appendix 5 . Complete wage equations are available on request. 
Appendix 5: Regional wage differentials, Regional productivity differentials, and percentage of workers covered by a firm-level collective agreement by joint committee

\begin{tabular}{|c|c|c|c|c|}
\hline $\begin{array}{l}\text { Number of } \\
\text { the Joint } \\
\text { Committee }\end{array}$ & Comparison & Wage differentials ${ }^{a}$ & $\begin{array}{l}\text { Productivity } \\
\text { differentials }\end{array}$ & $\begin{array}{c}\text { Percentage } \\
\text { of workers } \\
\text { covered by a } \\
\text { firm-level } \\
\text { agreement }^{\mathrm{c}}\end{array}$ \\
\hline 100 & Brussels-Flanders & -0.09 & -0.07 & 0.08 \\
\hline 100 & Brussels-Wallonia & -0.05 & -0.27 & 0.08 \\
\hline 100 & Flanders-Wallonia & 0.11 & -0.22 & 0.08 \\
\hline 105 & Flanders-Wallonia & -0.01 & 0.29 & 0.83 \\
\hline 109 & Flanders-Wallonia & -0.02 & 0.84 & 0.02 \\
\hline 111 & Brussels-Flanders & -0.06 & -0.08 & 0.47 \\
\hline 111 & Brussels-Wallonia & -0.03 & 0.02 & 0.47 \\
\hline 111 & Flanders-Wallonia & 0.01 & 0.11 & 0.47 \\
\hline 112 & Brussels-Flanders & -0.02 & 0.17 & 0.05 \\
\hline 112 & Brussels-Wallonia & 0.05 & 0.66 & 0.05 \\
\hline 112 & Flanders-Wallonia & 0.05 & 0.42 & 0.05 \\
\hline 115 & Flanders-Wallonia & -0.06 & -0.09 & 0.67 \\
\hline 116 & Brussels-Flanders & -0.07 & -0.27 & 0.68 \\
\hline 116 & Brussels-Wallonia & 0.05 & -0.19 & 0.68 \\
\hline 116 & Flanders-Wallonia & 0.08 & 0.10 & 0.68 \\
\hline 118 & Brussels-Flanders & 0.00 & 0.25 & 0.36 \\
\hline 118 & Brussels-Wallonia & 0.05 & 0.21 & 0.36 \\
\hline 118 & Flanders-Wallonia & 0.03 & -0.03 & 0.36 \\
\hline 119 & Brussels-Flanders & 0.08 & -0.20 & 0.20 \\
\hline 119 & Brussels-Wallonia & 0.03 & 0.03 & 0.20 \\
\hline 119 & Flanders-Wallonia & -0.03 & 0.28 & 0.20 \\
\hline 120 & Flanders-Wallonia & -0.05 & -0.06 & 0.13 \\
\hline 121 & Brussels-Flanders & -0.02 & 0.12 & 0.22 \\
\hline 121 & Brussels-Wallonia & -0.03 & -0.09 & 0.22 \\
\hline 121 & Flanders-Wallonia & -0.03 & -0.18 & 0.22 \\
\hline 124 & Brussels-Flanders & -0.02 & 0.07 & 0.00 \\
\hline 124 & Brussels-Wallonia & 0.00 & 0.19 & 0.00 \\
\hline
\end{tabular}




\begin{tabular}{|c|c|c|c|c|}
\hline 124 & Flanders-Wallonia & 0.01 & 0.11 & 0.00 \\
\hline 126 & Brussels-Flanders & -0.01 & -0.38 & 0.15 \\
\hline 126 & Brussels-Wallonia & -0.01 & -0.29 & 0.15 \\
\hline 126 & Flanders-Wallonia & -0.01 & 0.15 & 0.15 \\
\hline 129 & Flanders-Wallonia & -0.06 & -0.39 & 1.00 \\
\hline 130 & Brussels-Flanders & 0.04 & 0.04 & 0.23 \\
\hline 130 & Brussels-Wallonia & -0.08 & -0.01 & 0.23 \\
\hline 130 & Flanders-Wallonia & -0.12 & -0.05 & 0.23 \\
\hline 136 & Brussels-Flanders & -0.03 & -0.17 & 0.61 \\
\hline 136 & Brussels-Wallonia & 0.10 & -0.16 & 0.61 \\
\hline 136 & Flanders-Wallonia & 0.12 & 0.01 & 0.61 \\
\hline 140 & Brussels-Flanders & -0.08 & -0.32 & 0.14 \\
\hline 140 & Brussels-Wallonia & -0.02 & -0.28 & 0.14 \\
\hline 140 & Flanders-Wallonia & 0.07 & 0.06 & 0.14 \\
\hline 142 & Flandre-Wallonie & -0.07 & -0.05 & 0.03 \\
\hline 149 & Brussels-Flanders & -0.06 & -0.09 & 0.04 \\
\hline 149 & Brussels-Wallonia & -0.02 & 0.12 & 0.04 \\
\hline 149 & Flanders-Wallonia & 0.05 & 0.23 & 0.04 \\
\hline 201 & Brussels-Flanders & -0.09 & -0.27 & 0.01 \\
\hline 201 & Brussels-Wallonia & 0.01 & 0.04 & 0.01 \\
\hline 201 & Flanders-Wallonia & 0.17 & 0.43 & 0.01 \\
\hline 202 & Brussels-Flanders & 0.06 & 0.01 & 0.25 \\
\hline 202 & Brussels-Wallonia & 0.05 & 0.07 & 0.25 \\
\hline 202 & Flanders-Wallonia & -0.01 & 0.06 & 0.25 \\
\hline 207 & Brussels-Flanders & 0.02 & -0.13 & 0.45 \\
\hline 207 & Brussels-Wallonia & 0.10 & 0.00 & 0.45 \\
\hline 207 & Flanders-Wallonia & 0.04 & 0.15 & 0.45 \\
\hline 209 & Brussels-Flanders & -0.03 & -0.01 & 0.38 \\
\hline 209 & Brussels-Wallonia & 0.02 & 0.15 & 0.38 \\
\hline 209 & Flanders-Wallonia & 0.02 & 0.16 & 0.38 \\
\hline 211 & Brussels-Flanders & 0.02 & -0.35 & 0.05 \\
\hline 214 & Flanders-Wallonia & 0.02 & 0.19 & 0.06 \\
\hline 215 & Flanders-Wallonia & 0.04 & 0.08 & 0.06 \\
\hline
\end{tabular}




\begin{tabular}{|c|c|c|c|c|}
\hline 218 & Brussels-Flanders & 0.01 & 1.04 & 0.10 \\
\hline 218 & Brussels-Wallonia & 0.05 & 1.16 & 0.10 \\
\hline 218 & Flanders-Wallonia & 0.03 & 0.06 & 0.10 \\
\hline 220 & Brussels-Flanders & 0.09 & 0.46 & 0.31 \\
\hline 220 & Brussels-Wallonia & 0.15 & 0.78 & 0.31 \\
\hline 220 & Flanders-Wallonia & 0.05 & 0.22 & 0.31 \\
\hline 222 & Flanders-Wallonia & 0.08 & 0.01 & 0.20 \\
\hline 224 & Flanders-Wallonia & -0.03 & 0.16 & 0.82 \\
\hline 226 & Brussels-Flanders & 0.06 & 0.40 & 0.35 \\
\hline 226 & Brussels-Wallonia & 0.07 & 0.77 & 0.35 \\
\hline 226 & Flanders-Wallonia & 0.03 & 0.27 & 0.35 \\
\hline 302 & Brussels-Flanders & 0.00 & 0.09 & 0.00 \\
\hline 302 & Brussels-Wallonia & -0.04 & 0.13 & 0.00 \\
\hline 302 & Flanders-Wallonia & -0.02 & 0.04 & 0.00 \\
\hline 307 & Flanders-Wallonia & 0.00 & 0.36 & 0.35 \\
\hline 311 & Brussels-Flanders & -0.08 & -0.04 & 0.55 \\
\hline 311 & Brussels-Wallonia & -0.01 & -0.02 & 0.55 \\
\hline 311 & Flanders-Wallonia & 0.02 & 0.02 & 0.55 \\
\hline 312 & Brussels-Flanders & -0.08 & 0.13 & 0.69 \\
\hline 312 & Brussels-Wallonia & -0.06 & 0.01 & 0.69 \\
\hline 312 & Flanders-Wallonia & 0.02 & -0.11 & 0.69 \\
\hline 313 & Brussels-Flanders & -0.08 & 0.00 & 0.57 \\
\hline 313 & Brussels-Wallonia & 0.05 & 0.33 & 0.57 \\
\hline 313 & Flanders-Wallonia & 0.12 & 0.34 & 0.57 \\
\hline 328 & Brussels-Flanders & -0.04 & 0.10 & 0.64 \\
\hline 328 & Brussels-Wallonia & 0.09 & 0.20 & 0.64 \\
\hline 328 & Flanders-Wallonia & 0.08 & 0.10 & 0.64 \\
\hline
\end{tabular}

$a$ a: Computed on the basis on the wage equations estimates (cf. appendix 4$) ;{ }^{b}$ Differential between the mean value added-per-worker in region 1 and in region 2, within the same joint committee. ${ }^{c}$ : All regions taken together. 